\title{
Pastoral da Saúde: um Exercito de Voluntários a Serviço do Paciente
}

\author{
Lima, Diego Pereira; Araújo, Caroline Aparecida S. \\ Hospital Geral de Carapicuíba — cihumanizacao@hgcarapicuiba.org.br
}

Introdução a Pastoral da saúde é o setor responsável pelo recrutamento, organização e gestão dos voluntários e dos trabalhos desenvolvidos pelos mesmos, atuando em parceria com o Centro Integrado de Humanização e sendo o grande braço social da instituição. Objetivos Articular o grupo de voluntários de modo a oferecer ao paciente um período de internação mais humano e condizente com sua realizado fora do Hospital. Metodo a Pastoral da Saúde atua de maneira integrada com todos os setores do Hospital, alicerçada sobre três pilares fundamentais: $\bullet$ Espiritual $\bullet$ Social $\bullet$ Assistencial com cerca de 10 trabalhos e projetos desenvolvidos por voluntários, a Pastoral da Saúde consegue suprir a demanda que se faz existente em diversas áreas, como: •Brinquedoteca •Apoio Nutricional na Hemodiálise -Visitas Religiosas ecumênicas -Grupos de auto cuidado (corte de cabelo, manicure, penteados...) •Missas e sacramentos •Biblioteca do Bem (disponível a pacientes e colaboradores) -Projeto Sorrir (grupos lúdicos travestidos de palhaços) • Música no $\mathrm{Ar}$ (grupos de Corais) -Bazar do bem: o Bazar do Bem é um projeto desenvolvido pelo corpo de voluntários e administrado pela Pastoral da Saúde. Consiste em um ambiente onde os voluntários recebem doações de roupas, brinquedos e outros objetos, organiza e os vendem por valores simbólicos de no máximo $R \$ 2,00$. Todo o valor arrecadado com o Bazar do Bem é revertido em auxilio aos pacientes em situação de vulnerabilidade social através de cestas básicas, fraldas, kits de higiene, remédios entre outras necessidades. É reconhecido por toda a comunidade (Colaboradores, pacientes e sociedade) como um grande e importante projeto social que efetivamente possui resolutividade. Resultados É latente a percepção da equipe assistencial para com os resultados obtidos com o trabalho da pastoral da Saúde, os pacientes se mostram mais dispostos, receptíveis ao tratamento. Além da melhoria na satisfação dos pacientes, notada na inversão do numero de reclamações e elogios. Antes da Pastoral da saúde, em 2009, houve uma médica mensal de 87 reclamações e 13 elogios, no ano de 2013 com a Pastoral da Saúde consolidada e com todos os projetos em andamento houveram 31 reclamações e 90 elogios em média. Conclusão: a Pastoral da saúde desempenha uma função extraordinária que avança além da sua principal característica que é o atendimento espiritual, e esse avanço nas atividades do grupo de voluntários reflete diariamente nos corredores do Hospital e funciona na pratica como o grande braço de humanização e apoio espiritual e social da instituição.

Lima, Diego Pereira; Araújo, Caroline Aparecida S.. Pastoral da Saúde: um Exercito de Voluntários a Serviço do Paciente. In: Anais do Congresso Internacional de Humanidades \& Humanização em Saúde [= Blucher Medical Proceedings, num.2, vol.1]. São Paulo: Editora Blucher, 2014. ISSN 2357-7282 DOI 10.5151/medpro-cihhs-10572 